
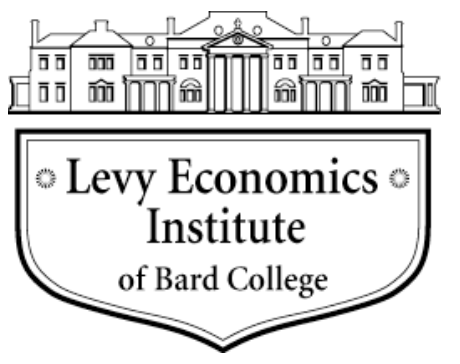

Working Paper No. 641

\title{
Disaggregating the Resource Curse: Is the Curse More Difficult to Dispel in Oil States than in Mineral States?
}

\author{
by \\ Timothy Azarchs \\ Tamar Khitarishvili* \\ Levy Economics Institute of Bard College
}

December 2010

\begin{abstract}
* The authors would like to thank Shelley Norman for providing resource abundance data. We are grateful to seminar participants at Bard College and the Workshop in Macroeconomic Research at Liberal Arts Colleges 2010, Colgate University, for helpful comments.
\end{abstract}

The Levy Economics Institute Working Paper Collection presents research in progress by Levy Institute scholars and conference participants. The purpose of the series is to disseminate ideas to and elicit comments from academics and professionals.

Levy Economics Institute of Bard College, founded in 1986, is a nonprofit, nonpartisan, independently funded research organization devoted to public service. Through scholarship and economic research it generates viable, effective public policy responses to important economic problems that profoundly affect the quality of life in the United States and abroad.

Levy Economics Institute P.O. Box 5000

Annandale-on-Hudson, NY 12504-5000

http://www.levyinstitute.org

Copyright (C) Levy Economics Institute 2010 All rights reserved 


\begin{abstract}
The hypothesis of the natural resource curse has captivated the economics profession, and since the mid-1990s has generated a large body of policymaking initiatives aimed at dispelling the curse. In this paper, we evaluate how the effect of resource abundance on economic growth has changed since these policies were first introduced by comparing the periods 1970-89 and 19962008. We disaggregate resources into oil, gas, coal, and nonfuel mineral resources, and find that disaggregation unmasks diverse effects of resources on concurrent economic and institutional outcomes, as well as on the ability of countries to transform their economic and institutional infrastructure. We consider resource dependence and institutional quality as two channels linking resource abundance to economic growth in the context of an instrumental variables (IV) model. In addition to exploring these channels, the IV framework enables us to test for the endogeneity of the measures of resource dependence and institutional quality in the growth regressions, paying particular attention to the weakness of the instruments.
\end{abstract}

Keywords: Resource Curse; Resource Stocks; Resource Dependence; Rule of Law; Institutions; Economic Growth; Growth Regressions; Instrumental Variables

JEL Classifications: 011, 013, O4, Q3 


\section{INTRODUCTION}

Ever since Auty (1993) and Sachs and Warner (1995) postulated that the possession of natural resource wealth tends to lead to slower economic growth, the hypothesis of the resource curse has been in the spotlight of a large body of literature. The overall consensus appears to accept the presence of the resource curse between the 1970s and 1990s, although a number of more recent studies argue against it (Lederman and Maloney 2008). This rich academic literature has spawned numerous policymaking efforts aimed at dispelling the curse, ranging from direct tools, such as the taxation of commodity production, to more indirect tools, such as the establishment of managed floating exchange rate regimes and broader institutional reforms (Frankel, 2010).

By many accounts, the results of these efforts have been mixed (Weinthal and Luong 2006; Humphreys et al. 2007; Davis et al. 2001). Weinthal and Luong (2006) qualitatively evaluate the effectiveness of many implemented policies and conclude that only in a handful of countries have they been successful. Humphreys et al. (2007) focus on oil- and gas-rich countries and attempt to identify effective solutions based on the lessons learned from the experience of these countries.

In this paper, we argue that disaggregating resources into different types can shed light on the mixed economic outcomes achieved by resource-abundant countries since the early 1990s, when many of the policy initiatives aimed at addressing the curse were first introduced. We further contend that the resource type it possesses influences a country's ability to transform its institutional and economic infrastructure. The hypothesis that resource types matter to development is not new: industrial characteristics, such as factor intensities and ownership structure, as well as institutional foundation required for the development of different industries, can vary substantially (Humphreys et al. 2007). In line with this hypothesis, Leite and Weidmann (1999) find that fuel and ores, unlike agricultural resources, have a negative influence on institutional quality and economic growth. Sala-i-Martin and Subramanian (2003) and Isham et al. (2005) find that point-source (fuels and nonfuel minerals) and not diffuse (agriculture) resources have a significantly negative impact on institutional quality. But, unlike Leite and Weidmann (1999), these authors indicate that the effect of natural resources on economic growth (oil in the case of Sala-i-Martin and Subramanian [2003]) is positive. 
Our contribution to this literature lies in differentiating between resource abundance measures and resource dependence measures, which are commonly used in the literature as proxies for resource abundance (e.g., Leite and Weidmann 1999; Sala-i-Martin and Subramanian 2003; Isham et al. 2005; Boschini, Pettersson, and Roine 2007). Resource abundance represents the stock of resources whereas resource dependence represents the importance of resource extraction to the economy, a measure that is potentially endogenous in the growth equation. The endogeneity can occur if, for instance, the growth rate of a country with stagnant nonresource sectors is dragged down by these sectors, turning the economy more resource dependent. Moreover, slow-growing countries may intentionally increase their reliance on the resource sector in their attempt to increase their output. In such cases, even if resource dependence per se has a positive impact on economic growth, failing to control for endogeneity may result in inconsistent coefficient estimates and in the false appearance of a negative relationship.

Our measures of resource abundance come from Norman (2009), who constructs resource stock values in 1970 by combining the current reserves data with the production data between 1970 and the date the reserves were measured. Although not completely exogenous, Norman's (2009) measures are arguably closer to being exogenous than other available natural capital measures (Ploeg and Poelhekke 2010). Moreover, Norman’s (2009) data are available in disaggregated form, making our analysis possible. We take as a starting point the literature finding that mineral resources are the main culprit hurting development and consider the disaggregation into four categories: oil, gas, coal, and nonfuel mineral resources.

Humphreys et al. (2007) identify a number of channels through which resource abundance affects economic growth. In this paper, we focus primarily on two channels: resource dependence and institutional quality. Resource abundant countries tend to be more resource dependent, relying on natural resource exports for a larger share of their GDP. This reliance can, in turn, lead to output volatility from price shocks (Ploeg and Poelhekke 2010) and price distortions that hinder the traded goods sector (Corden and Neary 1982). This in turn prevents countries from developing the strong export manufacturing industries that are the flagship of modern development strategies (Sachs and Warner 1995). At the same time, resource abundance may erode institutional quality by providing increased opportunities for corruption and rent seeking (Leite and Weidmann 1999; Mehlum, Moene, and Torvik 2006) by encouraging the state to pursue policies beneficial to the resource extraction industry at the expense of other industries 
(Shafer 1994), or by creating rich elites that resist democratization and urbanization (Barro 1999; Ross 2001; Isham et al. 2005).

The paper compares the effect of disaggregated resource types on the economic performance of countries between 1970-89 and 1996-2008. Doing so allows us to identify the heterogeneous impact of resources not only on institutional quality, resource dependence, and economic growth, but also on the ability of countries to transform their institutional and economic infrastructure, which is our primary goal.

We use the instrumental variable approach to evaluate the potential endogeneity of the resource dependence and institutional quality in the growth equation. Whereas the instrumental variables approach can yield consistent coefficient estimates, this holds only if the instruments are sufficiently strong. In fact, the weakness of instruments, especially in the institutional quality regressions, is a common problem, which this study shares. We address the difficulties in interpreting the coefficient of the potentially endogenous variable by conducting a conditional likelihood ration (CLR) test (Moreira 2003; Shaw, Katsati, and Jurgilas 2010).

Insofar as we distinguish between resource dependence and resource abundance and evaluate the potential endogeneity of resource dependence and institutional quality, our paper is most closely related to Brunnschweiler and Bulte (2008), Ploeg and Poelhekke (2010), and Norman (2009). However, unlike Ploeg and Poelhekke (2010) and Brunnschweiler and Bulte (2008), we investigate the heterogeneity in the effect of resource types on resource dependence and economic growth. And, unlike Norman (2009), who also disaggregates the resource stock, in addition to the institutional channel, we explore the resource dependence channel connecting disaggregated resource abundance to economic growth. ${ }^{1}$ Moreover, unlike these authors, our primary interest lies in comparing the period that predates the introduction of policy shifts with the more recent period.

We begin by estimating our regressions using an aggregated measure of mineral resource abundance from Norman (2009), obtaining results that are consistent with similar specifications in Ploeg and Poelhekke (2010) and Brunnschweiler and Bulte (2008). The disaggregation into oil, gas, coal, and nonfuel minerals paints a more nuanced picture. Oil hurts institutional quality and resource dependence, confirming the findings of other studies, but has no direct effect on

\footnotetext{
${ }^{1}$ In addition, Norman (2009) divides disaggregated resource stock measures by GDP, doing which potentially weakens its exogeneity. Ding and Field (2005) also distinguish between resource abundance and resource dependence, but their main channel is human capital.
} 
economic growth. The impact of nonfuel minerals is manifested in increased resource dependence, but its effect on institutional quality or directly on economic growth is insignificant. Natural gas, in contrast, appears to affect growth through channels other than resource dependence or institutions. Comparing coefficients in the before and after period, we find that, as a whole, countries have not improved their handling of most resources. The notable exception is natural gas, whose direct effect on growth changes from significantly negative during 1970-89 to significantly positive during 1996-2008. It is also noteworthy that resource dependence appears negative but insignificant to growth in all specifications, similar to Ploeg and Poelhekke (2010) and Brunnschweiler and Bulte (2008). Neither resource dependence nor institutional quality is found to be endogenous, although the results with respect to institutional quality have to be interpreted with caution due to the weakness of instruments. Our results highlight the importance of disaggregation and the need to understand the relationship between resource type and the ability of countries to improve their economic and institutional performance.

The rest of the paper is organized as follows. In section 2, we discuss the specification of the model and the choice of instruments. Section 3 discusses the results in detail, including evaluating the endogeneity of resource dependence and institutional quality, correcting for the weakness of their instruments and exploring alternative specifications as a test of robustness. Section 4 concludes.

\section{MODEL SPECIFICATION}

We estimate two sets of instrumental variable regressions in order to evaluate resource dependence and institutional quality as two primary channels connecting resource abundance to growth. The first set of equations is:

$\operatorname{minxp} p_{t}=\alpha_{1}+\alpha_{2}$ open5060s $+\alpha_{3}$ pres $70 s+\alpha_{4}$ eurfrac $+\alpha_{5} \operatorname{minpc}+\alpha_{6} \lg d p 70+\alpha_{7}$ invgdpt + $\alpha_{8} h c_{t}+\alpha_{9}$ gpop $_{t}+\alpha_{10}$ regional dummies $+\varepsilon_{\text {minxp }}$

growth $_{t}=\beta_{1}+\beta_{2}$ minxp $_{t \text { fitted }}+\beta_{3}$ eurfrac $+\beta_{4}$ minpc $+\beta_{5} \operatorname{lgdp} 70+\beta_{6}$ invgdp $_{t}+\beta_{7} h c_{t}+\beta_{8}$ gpopt $+\beta_{9}$ regional dummies $+\varepsilon_{\text {growth }}$,

where we drop country-level subscripts, $t$ corresponds to either old period or new period; $\operatorname{minxp} p_{t}$ is GDP share of fuel and mineral exports averaged over the period; openness5060s is GDP share 
of trade volume averaged over 1950-69; pres70s is presidential dummy; eurfrac is the proportion of population speaking a European language; minpc is either aggregate per capita stock of mineral resources or disaggregated per capita stocks of oil, gas, coal, and nonfuel minerals, in which case $\alpha_{5}$ and $\beta_{4}$ are vectors; lgpd70 is log of real GDP per capita in 1970; $i n v g d p_{t}$ is GDP share of gross fixed capital formation averaged over the period; $h c_{t}$ is average years of schooling averaged over the period; gpop $_{t}$ is population growth rate averaged over the period; growth ${ }_{t}$ is growth rates in real GDP per capita averaged over the period; and $\varepsilon_{\text {minxp }}$ and $\varepsilon_{\text {growthl }}$ are the corresponding error terms.

The second set of equations is:

rule $_{t}=\gamma_{1}+\gamma_{2}$ latitude $+\gamma_{3}$ eurfrac $+\gamma_{4} \operatorname{minpc}+\gamma_{5} \operatorname{lgdp} 70+\gamma_{6}$ invgdp $_{t}+\gamma_{7} h c_{t}+\gamma_{8}$ gpop $_{t}+\gamma_{9}$ regional dummies $+\varepsilon_{\text {rule }}$

growth $_{t}=\delta_{1}+\delta_{2}$ rule $_{t f i t t e d}+\delta_{3}$ minpc $+\delta_{4} \lg d p 70+\delta_{5}$ invgdp $_{t}+\delta_{6}$ human $_{t}+\delta_{7}$ gpop $_{t}+\delta_{8}$ regional dummies $+\varepsilon_{\text {growth } 2}$,

where rule $_{t}$ represents the rule of law, and $\varepsilon_{\text {rule }}$ and $\varepsilon_{\text {growth } 2}$ are the corresponding error terms.

We include conventional measures in the growth equation (similar to Ploeg and Poelhekke [2010]). Note also that resource abundance measures appear in both growth equations to capture pathways other than institutional quality and resource dependence (see also Brunnschweiler and Bulte [2008]). When disaggregated measures are used, we include all four measures of resource abundance side by side. The fraction of the population speaking a European language, eurfrac (a common instrument for institutional quality), serves as an exogenous proxy for institutions in the resource dependence equation and resource abundance; minpc, serves as an exogenous proxy for resource dependence in the institutional quality regression.

The pool of instruments available for resource dependence is limited (Ploeg and Poelhekke; Brunnschweiler and Bulte 2008; Ding and Field 2005). Similar to Brunnschweiler and Bulte (2008), we choose average openness in the 1950s and 1960s, openness5060s, and the presidential dummy, pres70, as our instruments. Average openness in the 1950s and 1960s is intended to capture both geographic and institutional barriers to trade, which would affect the 
degree to which abundant resources are exported. Using a pre-period value limits the endogeneity of this measure as well as its impact on growth other than through resource dependence - while lagged effects from technological or expertise gains may exist, they are likely to be minimal twenty to thirty years later. The presidential regime dummy is coded as 1 for countries whose executive branch is directly elected and 0 for other (e.g., parliamentary) regime types. In a parliamentary system, MPs must vote along party lines or risk dissolution of the government and a new election, which would cost them their jobs. Members of congress have no such incentive, and so the legislative agenda must pander to the local concerns of committee heads and the special interest groups that contribute campaign money. Since resource extraction provides local jobs and tax dollars and the resource sector is one such special interest group, public policy is more likely to be skewed in its favor at the expense of the rest of the economy, leading to greater resource dependence (Brunnschweiler and Bulte 2008). These instruments are found to be strong and pass the overidentification tests of excludability and underidentification tests of relevance in both periods.

The existing literature on instrumenting for institutional quality is much broader, but the available instruments appear quite weak in these regressions. We chose the absolute value of latitude, latitude, and the fraction of the population speaking a European language, eurfrac, from Hall and Jones (1999), which are meant to capture attractiveness to European settlement and the degree of European influence, respectively. These two were the only instruments that passed both overidentification tests of excludability and underidentification tests of relevance in both periods. Other instruments including ethnolinguistic fractionalization, predicted trade share, European settlement in 1900, and settler mortality were evaluated but rejected on that basis.

While it may be preferable to estimate the two first stage regressions simultaneously and then put both endogenous variables into a single growth equation as Ploeg and Poelhekke (2010) do in some of their specifications, the available instruments are too weak to obtain consistent results in that framework. Since both first stages would have to contain the same right-hand-side variables, each one would have to contain both sets of instruments, diluting their explanatory power considerably. The already-weak instruments for institutional quality would also leave little independent variation between the two sets of fitted values, potentially resulting in multicollinearity issues in the growth equation. Hence, we adopt the framework in which the two channels are explored independently. 


\section{INTERPRETATION OF THE RESULTS}

In order to anchor our findings in the related literature that does not disaggregate the resource abundance, such as Ploeg and Poelhekke (2010) and Brunnschweiler and Bulte (2008), as a starting point we use an aggregate resource stock measure. Our results in tables 1 and 2 are generally consistent with these authors, finding that resource abundance contributes positively to resource dependence, but is insignificant to growth once dependence has been controlled for. The standard growth regressors included as controls have the expected signs, although significance varies across specifications. Compared to the old time period, resource abundance in the new period has an increasingly negative effect on institutional quality (again consistent with the usual finding of a negative or insignificant relationship between resource dependence and institutions, e.g., Isham et al. [2005] and Brunnschweiler and Bulte [2008]), while its effect through other channels remains unchanged. These results support the qualitative findings of Weinthal and Luong (2006) and Humphreys et al. (2007), who emphasize the difficulties of implementing policy measures to combat the resource curse.

Table 1: Aggregate Resource Abundance, 1970-1989

\begin{tabular}{|c|c|c|c|c|}
\hline & $\begin{array}{c}\text { Average Mineral } \\
\text { Resource Exports, } \\
\text { 1970-1989 } \\
\text { (\% GDP) }\end{array}$ & $\begin{array}{c}\text { Average Growth } \\
\text { in GDP/Capita, } \\
\text { 1970-1989 } \\
\text { (Constant 1990\$) }\end{array}$ & $\begin{array}{l}\text { Rule of Law, } \\
1996\end{array}$ & $\begin{array}{c}\text { Average Growth } \\
\text { in GDP/Capita, } \\
\text { 1970-1989 } \\
\text { (Constant 1990\$) }\end{array}$ \\
\hline & (1) & (2) & (3) & (4) \\
\hline \multicolumn{5}{|c|}{ 1970-1989 } \\
\hline Rule of Law, 1996 & & & & $\begin{array}{l}0.444^{\mathrm{a}} \\
(0.27)\end{array}$ \\
\hline $\begin{array}{l}\text { Average Mineral Resource } \\
\text { Exports/GDP, 1970-1989 (\%) }\end{array}$ & & $\begin{array}{l}-0.013^{\mathrm{a}} \\
(-0.39)\end{array}$ & & \\
\hline $\begin{array}{l}\text { Norman Log Value of Fuel Nonfuel } \\
\text { Mineral Stocks, } 1970 \text { (US\$/Capita) }\end{array}$ & $\begin{array}{l}1.447^{* * * *} \\
(4.25)\end{array}$ & $\begin{array}{l}-0.070 \\
(-0.99)\end{array}$ & $\begin{array}{l}-0.010 \\
(-0.55)\end{array}$ & $\begin{array}{l}-0.039 \\
(-0.60)\end{array}$ \\
\hline
\end{tabular}

Notes: $t$ statistics in parentheses; ${ }^{*} \mathrm{p}<.10,{ }^{* *} \mathrm{p}<.05,{ }^{* * *} \mathrm{p}<.01 ;{ }^{\text {a }}$ fitted value from previous column; complete tables in appendix 
Table 2: Aggregate Resource Abundance, 1996-2008

\begin{tabular}{|c|c|c|c|c|}
\hline & $\begin{array}{c}\text { Average Mineral } \\
\text { Resource Exports, } \\
\text { 1996-2008 } \\
\text { (\% GDP) }\end{array}$ & $\begin{array}{c}\text { Average Growth } \\
\text { in GDP/Capita, } \\
\text { 1996-2008 } \\
\text { (Constant 1990\$) }\end{array}$ & $\begin{array}{l}\text { Rule of Law, } \\
\text { Average of } \\
\text { 1996-2008 }\end{array}$ & $\begin{array}{c}\text { Average Growth } \\
\text { in GDP/Capita, } \\
\text { 1996-2008, } \\
\text { (Constant 1990\$) }\end{array}$ \\
\hline & (1) & (2) & (3) & (4) \\
\hline Rule of Law, Average of 1996-2008 & & & & $\begin{array}{l}1.528^{\mathrm{a}} \\
(1.49)\end{array}$ \\
\hline $\begin{array}{l}\text { Exports of Point Resources, Average } \\
\text { 1996-2008 (\% GDP) }\end{array}$ & & $\begin{array}{l}-0.033^{\mathrm{a}} \\
(-0.81)\end{array}$ & & \\
\hline $\begin{array}{l}\text { Norman Log Value of Fuel Nonfuel } \\
\text { Mineral Stocks, } 1970 \text { (US\$/Capita) }\end{array}$ & $\begin{array}{c}1.681 * * * \\
(4.92)\end{array}$ & $\begin{array}{l}0.057 \\
(0.72)\end{array}$ & $\begin{array}{c}-0.039 * * \\
(-2.34)\end{array}$ & $\begin{array}{l}0.078 \\
(1.11)\end{array}$ \\
\hline
\end{tabular}

Disaggregating the resource abundance figure reveals a more detailed picture (tables 3 and 4). Oil seems to be driving the curse on institutions, having a significantly negative effect on rule of law in both periods while no other resource has any measurable effect. This suggests that oil abundance poses the most significant risk to institutional quality, confirming the findings of Leite and Weidmann (1999), Sala-i-Martin and Subramanian (2003), and others. The effect of oil reserves on resource dependence is somewhat clouded by multicollinearity with gas reserves, but they are jointly significant in both periods and oil alone becomes marginally significant in the later period. There is no evidence of improvement between the two time periods, indicating that oil-rich countries have a particularly difficult time diversifying their economies and reforming their institutions. Indeed, oil's effect on resource dependence is significantly greater in the later period, suggesting that countries with abundant oil reserves are becoming less diversified, either due to Dutch Disease effects or active attempts to develop oil extraction at the expense of other industries. $^{2}$

Natural gas appears to affect growth through channels other than resource dependence or institutional quality. Moreover, the sign of the coefficient estimate in the growth regressions changes from negative for 1970-89 to positive for 1996-2008. This change is statistically significant in both sets of regressions (i.e., column 2, as well as column 4 in tables 3 and 4). ${ }^{3}$ This finding may be due to a variety of factors, from changes to the extraction industry as more countries develop the capacity to capture and export their gas reserves instead of flaring them to

\footnotetext{
${ }^{2}$ p-value 0.04 .

3 The result holds even though the modern coefficient in growth regression in column 4 of table 4 is by itself insignificant. The p values for the coefficient comparison are 0.00 for column 2 and 0.01 for column 4 .
} 
changes in price and volatility. In any case, it appears that countries rich in natural gas have been more successful in managing the impact of those resources than countries with other resources.

Positive effects of aggregate resources on resource dependence appear to be masking a significantly negative effect of coal reserves on resource dependence equation for 1970-89. This result can emerge because coal is more commonly used for domestic consumption, only marginally entering into the export dependence figure. ${ }^{4}$ If coal provides a source of cheap local fuel for generating electricity, it may even boost other sectors of the economy, hence reducing resource dependence. By 1996-2008, coal loses its significance to resource dependence, but begins to have a positive direct effect on growth, at least in the specification with an endogenously determined institutional quality (column 4, table 4). In both cases, coal is bucking the trend for other point-source resources, its effect having a significantly different sign from that of other resources and highlighting the need to look more closely at resource type in the resource curse literature.

Nonfuel minerals show modest evidence of a resource curse. This is an aggregate of 35 metals including gold, silver, iron, and tin. While a more specific measure, such as one that separates the precious metals, might seem preferable, there are too few countries with any given mineral resource to draw meaningful conclusions (particularly since the United States, Australia, and Canada tend to figure prominently among those countries). Nonfuel mineral reserves contribute positively to resource dependence in both periods and negatively to growth in the 1996-2008 period (again in the endogenous institutional quality specification, column 4 in table 4). Although nonfuel mineral abundance does not appear to have an effect on institutional quality in either period, the coefficient estimate for the more recent period is significantly lower, suggesting that countries with nonfuel minerals have similarly failed to insulate their institutions from the effects of resource abundance. ${ }^{5}$

\footnotetext{
${ }^{4}$ According to the US EIA, in 2009 only 5.5\% of domestic coal production was exported (US EIA [2]). ${ }^{5}$ p-value 0.02 .
} 
Table 3: Disaggregated Abundance 1970-1989

\begin{tabular}{|c|c|c|c|c|}
\hline & $\begin{array}{c}\text { Average Mineral } \\
\text { Resource } \\
\text { Exports/GDP, } \\
\text { 1970-1989 (\%) }\end{array}$ & $\begin{array}{c}\text { Average Growth } \\
\text { in GDP/Capita, } \\
\text { 1970-1989 } \\
\text { (Constant 1990\$) }\end{array}$ & $\begin{array}{c}\text { Rule of } \\
\text { Law, } 1996\end{array}$ & $\begin{array}{c}\text { Average Growth } \\
\text { in GDP/Capita, } \\
\text { 1970-1989 } \\
\text { (Constant 1990\$) }\end{array}$ \\
\hline & (1) & (2) & (3) & (4) \\
\hline Rule of Law, 1996 & & & & $\begin{array}{l}0.339^{\mathrm{a}} \\
(0.27)\end{array}$ \\
\hline $\begin{array}{l}\text { Average Mineral Resource } \\
\text { Exports/GDP, 1970-1989 (\%) }\end{array}$ & & $\begin{array}{l}-0.007^{\mathrm{a}} \\
(-0.17)\end{array}$ & & \\
\hline $\begin{array}{l}\text { Logged Value of Oil } \\
\text { Reserves/Capita, } 1971\end{array}$ & $\begin{array}{l}1.715 \\
(0.92)\end{array}$ & $\begin{array}{l}0.428 \\
(1.13)\end{array}$ & $\begin{array}{c}-0.254 * * \\
(-2.07)\end{array}$ & $\begin{array}{l}0.404 \\
(0.86)\end{array}$ \\
\hline $\begin{array}{l}\text { Logged Value of Natural Gas } \\
\text { Reserves/Capita, } 1971\end{array}$ & $\begin{array}{l}6.632 \\
(1.45)\end{array}$ & $\begin{array}{l}-1.385^{*} \\
(-1.82)\end{array}$ & $\begin{array}{l}0.207 \\
(0.95)\end{array}$ & $\begin{array}{c}-1.492 * * \\
(-2.38)\end{array}$ \\
\hline $\begin{array}{l}\text { Logged Value of Coal } \\
\text { Reserves/Capita, } 1971\end{array}$ & $\begin{array}{l}-2.419 * \\
(-1.78)\end{array}$ & $\begin{array}{l}0.113 \\
(0.28)\end{array}$ & $\begin{array}{l}-0.046 \\
(-0.61)\end{array}$ & $\begin{array}{l}0.499 \\
(0.93)\end{array}$ \\
\hline $\begin{array}{l}\text { Logged Value of Nonfuel Mineral } \\
\text { Reserves/Capita, } 1970\end{array}$ & $\begin{array}{c}2.390 * * \\
(2.54)\end{array}$ & $\begin{array}{l}-0.258 \\
(-1.60)\end{array}$ & $\begin{array}{l}0.052 \\
(1.20)\end{array}$ & $\begin{array}{l}-0.295 \\
(-1.59)\end{array}$ \\
\hline
\end{tabular}

Notes: $t$ statistics in parentheses; ${ }^{*} \mathrm{p}<.10,{ }^{* *} \mathrm{p}<.05,{ }^{* * *} \mathrm{p}<.01 ;{ }^{a}$ fitted value from previous column; complete tables in appendix

Table 4: Disaggregated Abundance 1996-2008

\begin{tabular}{|c|c|c|c|c|}
\hline & $\begin{array}{c}\text { Exports of Point } \\
\text { Resources, } \\
\text { Average 1996- } \\
2008 \text { (\% GDP) }\end{array}$ & $\begin{array}{c}\text { Average Growth } \\
\text { in GDP/Capita, } \\
\text { 1996-2008 } \\
\text { (Constant 1990\$) }\end{array}$ & $\begin{array}{l}\text { Rule of Law, } \\
\text { Average of } \\
\text { 1996-2008 }\end{array}$ & $\begin{array}{c}\text { Average Growth } \\
\text { in GDP/Capita, } \\
\text { 1996-2008 } \\
\text { (Constant 1990\$) }\end{array}$ \\
\hline & $(1)$ & $(2)$ & (3) & (4) \\
\hline Rule of Law, Average of 1996-2008 & & & & $\begin{array}{c}1.822^{* * a} \\
(2.00)\end{array}$ \\
\hline $\begin{array}{l}\text { Exports of Point Resources, average } \\
\text { 1996-2008 (\% GDP) }\end{array}$ & & $\begin{array}{l}-0.061^{\mathrm{a}} \\
(-1.40)\end{array}$ & & \\
\hline $\begin{array}{l}\text { Fraction of Population Speaking a } \\
\text { European Language }\end{array}$ & $\begin{array}{l}-2.578 \\
(-1.25)\end{array}$ & $\begin{array}{l}0.659 \\
(1.07)\end{array}$ & $\begin{array}{l}0.596 * * * \\
(3.36)\end{array}$ & \\
\hline $\begin{array}{l}\text { Logged Value of Oil } \\
\text { Reserves/Capita, } 1971\end{array}$ & $\begin{array}{l}8.589 * \\
(1.97)\end{array}$ & $\begin{array}{l}-0.016 \\
(-0.03)\end{array}$ & $\begin{array}{c}-0.315^{* * *} \\
(-3.03)\end{array}$ & $\begin{array}{l}0.048 \\
(0.11)\end{array}$ \\
\hline $\begin{array}{l}\text { Logged Value of Natural Gas } \\
\text { Reserves/Capita, } 1971\end{array}$ & $\begin{array}{l}-2.029 \\
(-0.31)\end{array}$ & $\begin{array}{c}1.428^{* *} \\
(2.20)\end{array}$ & $\begin{array}{l}0.267 \\
(1.39)\end{array}$ & $\begin{array}{l}0.985 \\
(1.39)\end{array}$ \\
\hline $\begin{array}{l}\text { Logged Value of Coal } \\
\text { Reserves/Capita, } 1971\end{array}$ & $\begin{array}{l}2.336 \\
(1.09)\end{array}$ & $\begin{array}{l}0.421 \\
(1.54)\end{array}$ & $\begin{array}{l}-0.007 \\
(-0.11)\end{array}$ & $\begin{array}{c}0.397^{*} \\
(1.69)\end{array}$ \\
\hline $\begin{array}{l}\text { Logged Value of Nonfuel Mineral } \\
\text { Reserves/Capita, } 1970\end{array}$ & $\begin{array}{c}1.556^{* *} \\
(2.17)\end{array}$ & $\begin{array}{l}-0.193 \\
(-1.32) \\
\end{array}$ & $\begin{array}{l}-0.027 \\
(-0.68)\end{array}$ & $\begin{array}{r}-0.256^{*} \\
(-1.81)\end{array}$ \\
\hline
\end{tabular}




\section{Table 5: Change over Time in the Effect of Resource Abundance}

\begin{tabular}{lllll} 
& Resource Dependence & $\begin{array}{l}\text { Growth from Resource } \\
\text { Dependence }\end{array}$ & Institutional Quality & $\begin{array}{l}\text { Growth from } \\
\text { Institutional Quality }\end{array}$ \\
\hline Aggregate & Unchanged & Unchanged & Worsened* & Unchanged \\
Oil & Worsened** & Unchanged & Unchanged & Unchanged \\
Natural Gas & Improved* $_{\text {Coal }}^{\text {Worsened** }}$ & Improved*** & Unchanged & Improved** \\
Non-fuel & Unchanged & Unchanged & Unchanged & Unchanged \\
\hline \hline
\end{tabular}

Notes: Wald test of the simple linear hypothesis that the corresponding coefficients in tables 1-4 are the same; "improvement” is considered a more positive effect except in the case of resource dependence where improvement is considered a more negative effect; * $\mathrm{p}<.10$, $* * \mathrm{p}<.05$, $* * *$ $\mathrm{p}<.01$.

In no case do we find a significant effect of resource dependence on growth. This result concurs with the findings of other papers, such as Ploeg and Poelhekke (2010) and Brunnschweiler and Bulte (2008), which separate resource abundance from dependence. The finding appears to suggest that a diversified economy has been of little benefit to growth in both periods, either because resource dependence has no effect on growth or because it has multiple counteracting effects. Ploeg and Poelhekke (2010), for instance, explain this finding by arguing that a positive effect on growth from the industry itself-whose profitability and ability to attract foreign capital might be a boon to the economy-is counterbalanced with a negative effect from increased output volatility.

At the same time, this result contrasts with that of single-stage models, such as Sachs and Warner (1995), which generally predict a negative effect of resource dependence on growth. We investigate the possibility that the significance found in single-stage models may be due to a downward bias in the estimates due to the endogeneity of the resource dependence variable. To that end, we perform both Durbin-Wu-Hausman and C-statistic tests on all specifications (Baum, Schaffer, and Stillman 2007). In all cases, we are unable to reject the null hypothesis of exogeneity of resource dependence to growth, suggesting that no such bias exists (see tables A3A6). We also explore the possibility that the lack of significance in the two-stage setup stems from the information of loss due to instrumentation. However, when we use OLS to estimate the growth equation with the same explanatory variables (column 2 of tables A5 and A6) but without instrumenting for resource dependence, resource dependence remains negative and insignificant. ${ }^{6}$ Moreover, the instruments for resource dependence are reasonably strong and the $\mathrm{R}^{2}$ terms show that $50-60 \%$ of the variation in resource dependence is captured by the model,

\footnotetext{
${ }^{6}$ Results not shown, but available on request; p-value is 0.17 for the $1970-89$ period and 0.19 for the 1996-2008 period.
} 
casting doubt on this explanation. We conjecture that the difference in the results is potentially due to the inclusion of our resource stock measures.

Our findings lend support to the use of OLS regressions for testing the effect of resource dependence on growth. Nevertheless, using the coefficient of resource dependence in the growth regression as evidence for or against the resource curse is at best incomplete because resource dependence is one of many channels through which resource abundance can influence economic growth. Importantly, the use of the two-stage specification allows us to evaluate these channels.

Similar to resource dependence, institutional quality also appears to have no significant effect on growth, except in the modern period with disaggregated resource abundance, where it has the expected sign (column 4, table 4). However in this case the interpretation of the coefficient of instrumented institutional quality is complicated by the weakness of the instruments, as can be seen from the low F-statistics (column 3 in tables A3-A6). Weak instruments are known to bias the standard errors of the coefficient estimate of the endogenous variable, rendering its interpretation invalid. We correct for this bias using Conditional Likelihood Ratio (CLR) test (Moreira 2003). The CLR reports the probability that the population coefficient for the endogenous variable is zero, and, despite the potential bias, the CLR statistic consistently confirms the significance or nonsignificance of the estimate. The corrected results confirm the lack of significance of the instrumented institutional quality (column 3 in tables A3A6). This result is consistent with that of Shaw, Katsati, and Jurgilas (2010) who find that corruption and bureaucratic efficiency measures are insignificant in IV regressions once the weakness of their instruments is taken into account, although previous authors who did not correct for weak instrumentation found significant relationships of the same sign (Shleifer and Vishny [1993], among others). Several factors might contribute to the lack of significance, including information loss from weak instrumentation and the use of a 1996 value to proxy for institutional quality as far back as $1970 .^{7}$ If the uninstrumented value for institutional quality is used in place of the instrumented one, it appears significantly positive at the $1 \%$ level in both periods. Similar to the resource dependence case, endogeneity tests provide no evidence that a two-stage framework used to instrument for institutional quality is necessary. However, the firststage results are sufficiently interesting in their own right to warrant a two-stage approach.

\footnotetext{
${ }^{7}$ Note also that, as Stock, Wright, and Yogo (2002) show, the coefficient estimates for exogenous variables are unbiased, provided that the independent variation in the variable being examined is not the sole predictor of the rule of law, an assumption we are comfortable making given the number of significant conditioning variables.
} 
As tests of robustness, we include two alternative specifications. The first is a 3SLS version of the resource dependence equations that takes advantage of the correlation between the error terms in the two stages to produce more efficient results (tables A8 and A9). The results from this specification are broadly similar, with a few variables gaining in significance thanks to the increased efficiency. A notable exception is coal, which appears to have a negative effect on resource dependence in the older period with 2SLS, but is insignificant in the 3SLS version. In tables A10 and A11, the 2SLS results for disaggregated resource abundance are repeated using the Grubbs maximum normed residual test to eliminate outliers. This test shows a markedly greater difference from the preferred specification, but that is not unexpected given that as much as one-quarter of the sample is being dropped, as well as the entire coal abundance variable. Oil loses significance in all stages and periods, while natural gas and nonfuel minerals become significantly negative to institutions.

\section{CONCLUSIONS}

This paper makes three contributions to the extensive literature on the resource curse. By disaggregating resource abundance into four categories, we see that even within the "pointresource" umbrella there is substantial variation in the effects of different resources through different channels. Although previous papers have looked at different resources, they have typically used either a potentially endogenous measure of resource abundance as a share of GDP (Sala-i-Martin and Subramanian 2003; Norman 2009) or compared separate regressions each with a single resource rather than examining them side-by-side in a single regression where other resource types are controlled for (Brunnschweiler and Bulte 2008). Furthermore, we use modern data to compare the most recent time period with the older period, on which most of the empirical literature is based. This allows us to evaluate the effectiveness of efforts to alleviate the resource curse on an empirical basis, in terms of outcomes for institutions and diversification, as well as growth. Combining the two time periods with disaggregated measures of resource abundance suggests that countries with specific resources have had different success rates. Finally, we update the methodology of resource curse regressions to consider the potential endogeneity of conventional resource abundance measures. 
Our results are generally in line with the findings of similar papers, in particular the conclusion that resource export dependence has no significant empirical effect on growth in an instrumental variables set up. The combination of disaggregated resource abundance and the before and after comparison give us some new insights into the resource curse, however. Oil appears to be the only resource to negatively affect institutions, a finding that is masked by aggregate figures. Different resources also seem to have dramatically different effects on resource dependence: a natural log increase in oil abundance has an estimated effect on export dependence that is five-times greater than a similar increase in metals, for instance, and coal abundance might actually be associated with a decrease in resource dependence. Natural gas, on the other hand, appears to affect growth through channels other than institutions and export dependence. Furthermore, our findings suggest that very little headway has been made in dispelling the curse of resources. For most resources, their effect on all three measures under consideration is worsened or unchanged in the modern period. The one exception is natural gas, which appears to be a curse in the old period but a boon in the new. This result once again highlights the importance of differentiating among resource types. The relatively short period that has passed since the introduction of policy efforts could be a factor contributing to the overall pessimistic picture.

These findings suggest several avenues for future research. If different resources have different effects, it remains to be investigated exactly why. Oil's strong negative effect on institutions might be due to its tendency to be publicly owned, as Quinn and Conway (2007) suggest. Public ownership provides increased access by politicians to resource revenue streams, increasing the danger of rent-seeking. On the other hand, the curse of oil might be due to industrial characteristics like its tendency to employ foreign labor rather than encouraging urbanization and investment in local human capital as more labor-intensive industries would. The finding that natural gas, in particular, has an effect on growth that is not via either institutional quality or export dependence also suggests a question for future research. Two channels not explored in this paper are human capital and output volatility, and while they have been discussed in the literature they have not been evaluated with respect to an exogenous, disaggregated measure of resource abundance. 


\section{APPENDIX}

Table A1: Description of Variables

\begin{tabular}{|c|c|c|c|c|}
\hline Variable & Description & Old & New & Source \\
\hline $\begin{array}{l}\text { Growth Rate, } \\
\text { growth }\end{array}$ & $\begin{array}{l}\text { Average of the yearly growth rates in GDP/capita } \\
\text { across sample years, constant } 1990 \text { dollars. }\end{array}$ & $\begin{array}{l}1970- \\
1989\end{array}$ & $\begin{array}{l}1996- \\
2008\end{array}$ & $\begin{array}{l}\text { UNSD National Accounts Main Agregates } \\
\text { Database, } \\
\text { http://unstats.un.org/unsd/snaama/Introduction.asp }\end{array}$ \\
\hline $\begin{array}{l}\text { Logged Oil } \\
\text { Abundance }\end{array}$ & $\begin{array}{l}\text { Natural log of the dollar value of oil } \\
\text { reserves/capita, 1971. Based on } 2002 \text { proven } \\
\text { reserves, 1971-2002 production, and } 1970 \text { world } \\
\text { prices. }\end{array}$ & 1971 & 1971 & Norman (2009) and UNSD (for population data) \\
\hline $\begin{array}{l}\text { Logged Natural } \\
\text { Gas } \\
\text { Abundance }\end{array}$ & $\begin{array}{l}\text { Natural log of the dollar value of natural gas } \\
\text { reserves/capita, 1971. Based on } 2002 \text { proven } \\
\text { reserves, 1971-2002 production, and } 1970 \text { world } \\
\text { prices. }\end{array}$ & 1971 & 1971 & Norman (2009) and UNSD (for population data) \\
\hline $\begin{array}{l}\text { Logged Coal } \\
\text { Abundance }\end{array}$ & $\begin{array}{l}\text { Natural log of the dollar value of coal } \\
\text { reserves/capita, 1971. Based on } 2002 \text { proven } \\
\text { reserves, 1971-2002 production, and } 1970 \text { world } \\
\text { prices. }\end{array}$ & 1971 & 1971 & Norman (2009) and UNSD (for population data) \\
\hline $\begin{array}{l}\text { Logged } \\
\text { Nonfuel } \\
\text { Mineral } \\
\text { Abundance } \\
\end{array}$ & $\begin{array}{l}\text { Natural log of the dollar value of } 35 \text { metal and } \\
\text { mineral reserves/capita, } 1970 \text {. Based on } 2002 \\
\text { proven reserves, 1970-2002 production, and } 1970 \\
\text { world prices. }\end{array}$ & 1970 & 1970 & Norman (2009) and UNSD (for population data) \\
\hline $\begin{array}{l}\text { Logged } \\
\text { Aggregate } \\
\text { Mineral } \\
\text { Abundance } \\
\end{array}$ & $\begin{array}{l}\text { Natural log of the dollar value of oil, natural gas, } \\
\text { coal, and } 35 \text { metal and mineral reserves/capita, } \\
1970 . \text { Based on } 2002 \text { proven reserves, 1970-2002 } \\
\text { production, and } 1970 \text { world prices. }\end{array}$ & 1970 & 1970 & $\begin{array}{l}\text { Brunnschweiler and Bulte (2008) from Norman } \\
\text { (2009). }\end{array}$ \\
\hline $\begin{array}{l}\text { Mineral } \\
\text { Exports, minxp }\end{array}$ & $\begin{array}{l}\text { GDP share of total yearly fuel and mineral exports } \\
\text { (SITC } 3,27,28,68 \text { ), averaged over period. }\end{array}$ & $\begin{array}{l}1970- \\
1989\end{array}$ & $\begin{array}{l}1996- \\
2008\end{array}$ & $\begin{array}{l}\text { Old: Brunnschweiler and Bulte (2008) from WDI, } \\
\text { PWT 6.1 } \\
\text { New: UNCTAD Handbook of Statistics } 2009 \\
\text { http://stats.unctad.org/Handbook/ and UNSD (for } \\
\text { GDP figures). }\end{array}$ \\
\hline $\begin{array}{l}\text { Rule of Law, } \\
\text { rule }\end{array}$ & $\begin{array}{l}\text { Perceptions of the quality of contract enforcement, } \\
\text { property rights, the police, and the courts, as well } \\
\text { as the likelihood of crime and violence. }\end{array}$ & 1996 & $\begin{array}{l}1996- \\
2008\end{array}$ & $\begin{array}{l}\text { Kaufmann, Kraay, and Mastruzzi (2009). World } \\
\text { Bank World Governance Indicators dataset } \\
\text { http://info.worldbank.org/ } \\
\text { governance/wgi/index.asp }\end{array}$ \\
\hline $\begin{array}{l}\text { Logged } \\
\text { GDP/Capita, } \\
1970\end{array}$ & Log of real GDP/capita in 1970. & & & $\begin{array}{l}\text { Brunnschweiler and Bulte (2008) from Penn } \\
\text { World Tables } 6.1\end{array}$ \\
\hline $\begin{array}{l}\text { Investment } \\
\text { Rate, } \\
\text { invgdp }\end{array}$ & $\begin{array}{l}\text { Gross fixed capital formation as a fraction of GDP, } \\
\text { averaged over the sample period. }\end{array}$ & $\begin{array}{l}1970- \\
1989\end{array}$ & $\begin{array}{l}1996- \\
2008\end{array}$ & $\begin{array}{l}\text { UNSD National Accounts Main Agregates } \\
\text { Database, } \\
\text { http://unstats.un.org/unsd/ } \\
\text { snaama/Introduction.asp }\end{array}$ \\
\hline $\begin{array}{l}\text { Average Years } \\
\text { of Schooling, } \\
h c\end{array}$ & $\begin{array}{l}\text { Average years of schooling in adults, measured } \\
\text { every five years and averaged over period. }\end{array}$ & $\begin{array}{l}1970- \\
1990\end{array}$ & $\begin{array}{l}1995- \\
2000\end{array}$ & Barro and Lee (2000) \\
\hline $\begin{array}{l}\text { Population } \\
\text { Growth, } \\
\text { gpop }\end{array}$ & $\begin{array}{l}\text { Average of yearly population growth over the } \\
\text { sample period. }\end{array}$ & $\begin{array}{l}1970- \\
1989\end{array}$ & $\begin{array}{l}1996- \\
2008\end{array}$ & $\begin{array}{l}\text { UNSD National Accounts Main Agregates } \\
\text { Database, http://unstats.un.org/unsd// } \\
\text { snaama/Introduction.asp }\end{array}$ \\
\hline $\begin{array}{l}\text { Average } \\
\text { Openness, } \\
\text { 1950-1969, } \\
\text { openness5060s }\end{array}$ & $\begin{array}{l}\text { Exports + imports as a fraction of GDP, averaged } \\
\text { over the years 1950- } 69 \text {. }\end{array}$ & $\begin{array}{l}1950- \\
1969\end{array}$ & $\begin{array}{l}1950- \\
1969\end{array}$ & Brunnschweiler and Bulte (2008) from PST 6.1 \\
\hline $\begin{array}{l}\text { Presidential } \\
\text { Regime } \\
\text { Dummy, } \\
\text { pres } 70\end{array}$ & $\begin{array}{l}\text { Binary indicator reads } 1 \text { for a presidential system, } \\
0 \text { for parliamentary. }\end{array}$ & 1970 & 1970 & $\begin{array}{l}\text { Brunnschweiler and Bulte (2008) from Beck et al. } \\
\text { (2005) and Persson and Tabellini (2004) }\end{array}$ \\
\hline Latitude & Absolute value of latitude on a $0-1$ scale. & NA & NA & $\begin{array}{l}\text { Brunnschweiler and Bulte (2008) from La Porta et } \\
\text { al. (1999) }\end{array}$ \\
\hline $\begin{array}{l}\text { European } \\
\text { Language, } \\
\text { eurfrac }\end{array}$ & $\begin{array}{l}\text { Fraction of the population speaking English, } \\
\text { French, German, Portuguese, or Spanish as their } \\
\text { first language. }\end{array}$ & Varies & Varies & $\begin{array}{l}\text { Hall and Jones (1999) } \\
\text { http://www.stanford.edu/ chadj/HallJones400.asc }\end{array}$ \\
\hline $\begin{array}{l}\text { Regional } \\
\text { Dummies }\end{array}$ & $\begin{array}{l}\text { Four regional dummies for Africa and the Middle } \\
\text { East, Asia and Oceania Central and South } \\
\text { America, and North America. The reference region } \\
\text { is Europe. }\end{array}$ & NA & NA & Brunnschweiler and Bulte (2008) \\
\hline
\end{tabular}


Table A2: Summary Statistics

\begin{tabular}{|c|c|c|c|c|c|c|c|c|}
\hline \multirow{2}{*}{ Variable } & \multicolumn{2}{|c|}{ Mean } & \multicolumn{2}{|c|}{ Std. Dev. } & \multicolumn{2}{|c|}{ Min } & \multicolumn{2}{|c|}{ Max } \\
\hline & Old & New & Old & New & Old & New & Old & New \\
\hline Growth & 1.607 & 2.309 & 1.708 & 1.621 & -2.320 & -3.887 & 7.114 & 8.755 \\
\hline $\begin{array}{l}\text { Logged Oil } \\
\text { Abundance }\end{array}$ & 0.432 & & 0.821 & & 0 & & 3.573 & \\
\hline $\begin{array}{l}\text { Logged Gas } \\
\text { Abundance }\end{array}$ & 0.197 & & 0.424 & & 0 & & 1.883 & \\
\hline $\begin{array}{l}\text { Logged Coal } \\
\text { Abundance }\end{array}$ & 0.220 & & 0.666 & & 0 & & 3.870 & \\
\hline $\begin{array}{l}\text { Logged Nonfuel } \\
\text { Mineral Abundance }\end{array}$ & 0.866 & & 1.302 & & 0 & & 5.359 & \\
\hline $\begin{array}{l}\text { Logged Aggregate } \\
\text { Mineral Abundance }\end{array}$ & 7.078 & & 3.015 & & -16.393 & & 1.553 & \\
\hline Mineral Exports & 5.990 & 6.941 & 9.320 & 10.528 & 0.009 & 0.037 & 43.737 & 69.504 \\
\hline Rule of Law & 0.198 & 0.128 & 1.030 & 1.023 & -1.457 & -1.565 & 2.036 & 1.949 \\
\hline $\begin{array}{l}\text { Logged GDP/Capita } \\
1970\end{array}$ & 6.927 & & 0.946 & & 5.189 & & 8.677 & \\
\hline Investment Rate & 21.757 & 21.378 & 5.649 & 5.531 & 8.521 & 7.365 & 37.955 & 40.416 \\
\hline Average Education & 4.547 & 5.968 & 2.743 & 2.860 & 0.380 & 0.730 & 11.080 & 12.220 \\
\hline $\begin{array}{l}\text { Average Population } \\
\text { Growth }\end{array}$ & 1.954 & 1.511 & 1.077 & 0.964 & -0.346 & -0.452 & 3.764 & 4.615 \\
\hline Openness 1950-69 & 0.498 & & 0.346 & & 0.062 & & 2.672 & \\
\hline Presidential Dummy & 0.602 & & 0.492 & & 0 & & 1 & \\
\hline European Language & 0.328 & & 0.420 & & 0 & & 1 & \\
\hline Latitude & 0.277 & & 0.193 & & 0.010 & & 0.720 & \\
\hline
\end{tabular}

\section{Sample Countries (* for Grubbs Outlier in at least 1 regression)}

Africa and the Middle East: Algeria,* Benin, Botswana,* Burundi, Cameroon, Central African Republic, Republic of the Congo,* Egypt,* Gambia,* Ghana, Iran,* Israel, Jordan, Kenya, Lesotho,* Malawi, Mali, Mauritania,* Mauritius, Mozambique, Niger, Rwanda, Senegal, Sierra Leone, South Africa, Syrian Arab Republic,* Togo, Tunisia, Uganda, Zambia,* Zimbabwe*

Asia and Oceania: Australia,* Bangladesh, China,* Fiji, India, Indonesia,* Japan, Malaysia,* Nepal, New Zealand,* Pakistan, Philippines, Singapore,* Sri Lanka, Thailand

Central and South America: Argentina,* Barbados, Bolivia,* Brazil, Chile,* Colombia, Costa Rica, Dominican Republic, Ecuador,* El Salvador, Guatemala, Guyana,* Haiti, Honduras, Jamaica,* Mexico, Nicaragua, Panama, Paraguay, Peru, Puerto Rico, Trinidad and Tobago,* Uruguay, Venezuela*

North America: Canada,* United States*

Europe (reference category): Austria, Belgium, Cyprus, Denmark,* Finland, France, Greece, Hungary, Iceland, Ireland, Italy, Netherlands.* Norway,* Poland, Portugal, Romania,* Spain, Sweden, Switzerland, Turkey, United Kingdom* 
Table A3: Aggregate Resource Abundance, 1970-1989

\begin{tabular}{|c|c|c|c|c|}
\hline & $\begin{array}{c}(1) \\
\text { Average Mineral } \\
\text { Resource } \\
\text { Exports/GDP, } \\
\text { 1970-1989 (\%) }\end{array}$ & $\begin{array}{c}\text { (2) } \\
\text { Average Growth } \\
\text { in GDP/Capita, } \\
\text { 1970-1989 } \\
\text { (Constant 1990\$) }\end{array}$ & $\begin{array}{c}(3) \\
\text { Rule of } \\
\text { Law, } 1996\end{array}$ & $\begin{array}{c}(4) \\
\text { Average Growth } \\
\text { in GDP/Capita, } \\
\text { 1970-1989 } \\
\text { (Constant 1990\$) }\end{array}$ \\
\hline Rule of Law, 1996 & & & & $\begin{array}{l}0.444^{\mathrm{a}} \\
(0.27)\end{array}$ \\
\hline $\begin{array}{l}\text { Average Mineral Resource } \\
\text { Exports/GDP, 1970-89 (\%) }\end{array}$ & & $\begin{array}{l}-0.013^{\mathrm{a}} \\
(-0.39)\end{array}$ & & \\
\hline $\begin{array}{l}\text { Average Openness, } 1950-69 \\
\text { (Ex+Im/GDP) }\end{array}$ & $\begin{array}{l}15.589 * * * \\
(5.17)\end{array}$ & & & \\
\hline Presidential Regime Dummy, 1970s & $\begin{array}{l}3.821 \\
(1.19)\end{array}$ & & & \\
\hline $\begin{array}{l}\text { Absolute Value of Latitude on } 0-1 \\
\text { Scale }\end{array}$ & & & $\begin{array}{l}0.755 \\
(1.56)\end{array}$ & \\
\hline $\begin{array}{l}\text { Fraction of Population Speaking a } \\
\text { European Language }\end{array}$ & $\begin{array}{l}-1.669 \\
(-0.84)\end{array}$ & $\begin{array}{l}-0.123 \\
(-0.20)\end{array}$ & $\begin{array}{l}0.339^{*} \\
(1.70)\end{array}$ & \\
\hline $\begin{array}{l}\text { Norman Log Value of Fuel Nonfuel } \\
\text { Mineral Stocks, } 1970 \text { (US\$/Capita) }\end{array}$ & $\begin{array}{c}1.447 * * * \\
(4.25)\end{array}$ & $\begin{array}{l}-0.070 \\
(-0.99)\end{array}$ & $\begin{array}{l}-0.010 \\
(-0.55)\end{array}$ & $\begin{array}{l}-0.039 \\
(-0.60)\end{array}$ \\
\hline Log GDP/Capita, 1970 & $\begin{array}{l}-0.082 \\
(-0.04)\end{array}$ & $\begin{array}{c}-1.353^{* * *} \\
(-3.14)\end{array}$ & $\begin{array}{l}0.375^{* * *} \\
(3.03)\end{array}$ & $\begin{array}{l}-1.473^{*} \\
(-1.70)\end{array}$ \\
\hline $\begin{array}{l}\text { Average Gross Fixed Capital } \\
\text { Formation, 1970-89 (\% of GDP) }\end{array}$ & $\begin{array}{l}0.274 \\
(1.55)\end{array}$ & $\begin{array}{c}0.174^{* * *} \\
(4.38)\end{array}$ & $\begin{array}{l}0.004 \\
(0.40)\end{array}$ & $\begin{array}{l}0.171^{* * *} \\
\quad(5.10)\end{array}$ \\
\hline $\begin{array}{l}\text { Average Years of Schooling, 1970- } \\
90\end{array}$ & $\begin{array}{l}-0.790^{*} \\
(-1.77)\end{array}$ & $\begin{array}{l}0.228 \\
(1.60)\end{array}$ & $\begin{array}{c}0.104^{* *} \\
(2.52)\end{array}$ & $\begin{array}{l}0.125 \\
(0.56)\end{array}$ \\
\hline $\begin{array}{l}\text { Average Growth in Population, } \\
\text { 1970-89 (\%) }\end{array}$ & $\begin{array}{l}-0.168 \\
(-0.12)\end{array}$ & $\begin{array}{l}-0.348 \\
(-1.18)\end{array}$ & $\begin{array}{l}-0.084 \\
(-0.93)\end{array}$ & $\begin{array}{l}-0.228 \\
(-0.63)\end{array}$ \\
\hline Constant & $\begin{array}{l}4.626 \\
(0.33)\end{array}$ & $\begin{array}{l}7.562 * * * \\
(2.73)\end{array}$ & $\begin{array}{c}-2.999 * * * \\
(-3.58)\end{array}$ & $\begin{array}{l}8.660 \\
(1.45)\end{array}$ \\
\hline Observations & 83 & 83 & 89 & 89 \\
\hline $\begin{array}{l}R^{2} \\
\text { F-test of Instruments }\end{array}$ & $\begin{array}{l}0.592 \\
21.38\end{array}$ & 0.525 & $\begin{array}{l}0.826 \\
2.25\end{array}$ & 0.461 \\
\hline Anderson Canon. Corr. & & 31.48 & & 4.91 \\
\hline Underidentification Test (p-value) & & $(0.00)$ & & $(0.09)$ \\
\hline $\begin{array}{l}\text { Sargan Overidentification Test } \\
\text { (p-value) }\end{array}$ & & $\begin{array}{c}0.01 \\
(0.92)\end{array}$ & & $\begin{array}{c}0.06 \\
(0.81)\end{array}$ \\
\hline Durbin Wu Hausman Endogeneity & & 1.17 & & 0.52 \\
\hline Test (p-value) & & $(0.25)$ & & $(0.60)$ \\
\hline Endogeneity Test (p-value) & & $1.60(0.21)$ & & $0.32(0.57)$ \\
\hline $\begin{array}{l}\text { CLR of Endogenous Variable p- } \\
\text { value }\end{array}$ & & 0.71 & & 0.82 \\
\hline
\end{tabular}


Table A4: Aggregate Abundance, 1996-2008

\begin{tabular}{|c|c|c|c|c|}
\hline & $\begin{array}{c}1) \\
\text { Exports of Point } \\
\text { Resources, } \\
\text { average 1996- } \\
2008 \text { (\% GDP) } \\
\end{array}$ & $\begin{array}{c}\text { (2) } \\
\text { Average Growth } \\
\text { in GDP/Capita, } \\
\text { 1996-2008, } \\
\text { (Constant 1990\$) }\end{array}$ & $\begin{array}{c}\text { (3) } \\
\text { Rule of Law, } \\
\text { Average of } \\
\text { 1996-2008 }\end{array}$ & $\begin{array}{c}\text { (4) } \\
\text { Average Growth } \\
\text { in GDP/Capita, } \\
\text { 1996-2008, } \\
\text { (Constant 1990\$) }\end{array}$ \\
\hline Rule of Law, Average of 1996-2008 & & & & $\begin{array}{l}1.528^{\mathrm{a}} \\
(1.49)\end{array}$ \\
\hline $\begin{array}{l}\text { Exports of Point Resources, average } \\
\text { 1996-2008 (\% GDP) }\end{array}$ & & $\begin{array}{l}-0.033^{\mathrm{a}} \\
(-0.81)\end{array}$ & & \\
\hline $\begin{array}{l}\text { Average Openness, 1950-69 } \\
(\text { Ex+Im/GDP) }\end{array}$ & $\begin{array}{l}12.752 * * * \\
\quad(4.55)\end{array}$ & & & \\
\hline Presidential Regime Dummy, 1970s & $\begin{array}{l}1.302 \\
(0.51)\end{array}$ & & & \\
\hline $\begin{array}{l}\text { Absolute Value of Latitude on } 0-1 \\
\text { Scale }\end{array}$ & & & $\begin{array}{c}1.082^{* *} \\
(2.42)\end{array}$ & \\
\hline $\begin{array}{l}\text { Fraction of Population Speaking a } \\
\text { European Language }\end{array}$ & $\begin{array}{l}-2.649 \\
(-1.27)\end{array}$ & $\begin{array}{l}0.480 \\
(0.75)\end{array}$ & $\begin{array}{l}0.535^{* * *} \\
(2.91)\end{array}$ & \\
\hline $\begin{array}{l}\text { Norman Log Value of Fuel Nonfuel } \\
\text { Mineral Stocks, } 1970 \text { (US\$/Capita) }\end{array}$ & $\begin{array}{c}1.681 * * * \\
(4.92)\end{array}$ & $\begin{array}{l}0.057 \\
(0.72)\end{array}$ & $\begin{array}{c}-0.039 * * \\
(-2.34)\end{array}$ & $\begin{array}{l}0.078 \\
(1.11)\end{array}$ \\
\hline Log GDP/Capita, 1970 & $\begin{array}{l}-1.293 \\
(-0.60)\end{array}$ & $\begin{array}{c}-1.188 * * * \\
(-2.84)\end{array}$ & $\begin{array}{l}0.383 * * * \\
(3.25)\end{array}$ & $\begin{array}{c}-1.700 * * \\
(-2.45)\end{array}$ \\
\hline $\begin{array}{l}\text { Average Fixed Capital Formation, } \\
\text { 1996-2008 (Share of GDP) }\end{array}$ & $\begin{array}{l}0.309 \\
(1.49)\end{array}$ & $\begin{array}{l}0.131 * * * \\
(3.33)\end{array}$ & $\begin{array}{l}0.030 * * * \\
(3.00)\end{array}$ & $\begin{array}{l}0.073 \\
(1.46)\end{array}$ \\
\hline $\begin{array}{l}\text { Average Years of Schooling, 1995- } \\
2000\end{array}$ & $\begin{array}{l}-0.322 \\
(-0.53)\end{array}$ & $\begin{array}{c}0.316^{* *} \\
(2.49)\end{array}$ & $\begin{array}{l}0.142 * * * \\
(4.04)\end{array}$ & $\begin{array}{l}0.001 \\
(0.00)\end{array}$ \\
\hline $\begin{array}{l}\text { Average Yearly Growth in } \\
\text { Population, 1996-2008 }\end{array}$ & $\begin{array}{l}-1.766 \\
(-1.63)\end{array}$ & $\begin{array}{l}0.132 \\
(0.52)\end{array}$ & $\begin{array}{c}0.171^{* *} \\
(2.33)\end{array}$ & $\begin{array}{l}-0.070 \\
(-0.24)\end{array}$ \\
\hline Constant & $\begin{array}{l}17.170 \\
(1.22)\end{array}$ & $\begin{array}{c}6.655^{* *} \\
(2.16)\end{array}$ & $\begin{array}{c}-4.698 * * * \\
(-5.59)\end{array}$ & $\begin{array}{c}13.076 * * \\
(2.12)\end{array}$ \\
\hline Observations & 85 & 85 & 88 & 88 \\
\hline $\begin{array}{l}R^{2} \\
\text { F-test of Instruments }\end{array}$ & $\begin{array}{c}0.507 \\
9.87\end{array}$ & 0.325 & $\begin{array}{c}0.854 \\
6.09\end{array}$ & 0.285 \\
\hline Anderson Canon. Corr. & & 18.29 & & 12.16 \\
\hline Underidentification Test (p-value) & & $(0.00)$ & & $(0.00)$ \\
\hline $\begin{array}{l}\text { Sargan Overidentification Test } \\
\text { (p-value) }\end{array}$ & & $\begin{array}{c}0.05 \\
(0.83)\end{array}$ & & $\begin{array}{c}0.64 \\
(0.42)\end{array}$ \\
\hline Durbin Wu Hausman Endogeneity & & 0.49 & & 0.68 \\
\hline Test (p-value) & & $(0.63)$ & & $(0.50)$ \\
\hline Endogeneity Test (p-value) & & $0.28(0.60)$ & & $0.52(0.47)$ \\
\hline $\begin{array}{l}\text { CLR of Endogenous Variable p- } \\
\text { value }\end{array}$ & & 0.43 & & 0.16 \\
\hline
\end{tabular}


Table A5: Disaggregated Abundance 1970-1989

\begin{tabular}{|c|c|c|c|c|}
\hline & $\begin{array}{c}(1) \\
\text { Average Mineral } \\
\text { Resource } \\
\text { Exports/GDP, } \\
\text { 1970-1989 (\%) } \\
\end{array}$ & $\begin{array}{c}(2) \\
\text { Average Growth } \\
\text { in GDP/Capita, } \\
\text { 1970-1989 } \\
\text { (Constant 1990\$) } \\
\end{array}$ & $\begin{array}{c}(3) \\
\text { Rule of } \\
\text { Law, } 1996\end{array}$ & $\begin{array}{c}(4) \\
\text { Average Growth } \\
\text { in GDP/Capita, } \\
\text { 1970-1989 } \\
\text { (Constant 1990\$) }\end{array}$ \\
\hline Rule of Law, 1996 & & & & $\begin{array}{l}0.339^{\mathrm{a}} \\
(0.27)\end{array}$ \\
\hline $\begin{array}{l}\text { Average Mineral Resource } \\
\text { Exports/GDP, 1970-89 (\%) }\end{array}$ & & $\begin{array}{l}-0.007^{\mathrm{a}} \\
(-0.17)\end{array}$ & & \\
\hline $\begin{array}{l}\text { Average Openness, 1950-69 } \\
\text { (Ex+Im/GDP) }\end{array}$ & $\begin{array}{l}12.886^{* * *} \\
(5.16)\end{array}$ & & & \\
\hline Presidential Regime Dummy, 1970s & $\begin{array}{l}4.209 \\
(1.58)\end{array}$ & & & \\
\hline $\begin{array}{l}\text { Absolute Value of Latitude on } 0-1 \\
\text { scale }\end{array}$ & & & $\begin{array}{l}0.652 \\
(1.33)\end{array}$ & \\
\hline $\begin{array}{l}\text { Fraction of Population Speaking a } \\
\text { European Language }\end{array}$ & $\begin{array}{l}-0.157 \\
(-0.08)\end{array}$ & $\begin{array}{l}-0.226 \\
(-0.37)\end{array}$ & $\begin{array}{c}0.410^{* *} \\
(2.07)\end{array}$ & \\
\hline $\begin{array}{l}\text { Logged Value of Oil } \\
\text { Reserves/Capita, } 1971\end{array}$ & $\begin{array}{l}1.715 \\
(0.92)\end{array}$ & $\begin{array}{l}0.428 \\
(1.13)\end{array}$ & $\begin{array}{c}-0.254 * * \\
(-2.07)\end{array}$ & $\begin{array}{l}0.404 \\
(0.86)\end{array}$ \\
\hline $\begin{array}{l}\text { Logged Value of Natural Gas } \\
\text { Reserves/Capita, } 1971\end{array}$ & $\begin{array}{l}6.632 \\
(1.45)\end{array}$ & $\begin{array}{l}-1.385^{*} \\
(-1.82)\end{array}$ & $\begin{array}{l}0.207 \\
(0.95)\end{array}$ & $\begin{array}{c}-1.492 * * \\
(-2.38)\end{array}$ \\
\hline $\begin{array}{l}\text { Logged Value of Coal } \\
\text { Reserves/Capita, } 1971\end{array}$ & $\begin{array}{l}-2.419 * \\
(-1.78)\end{array}$ & $\begin{array}{l}0.113 \\
(0.28)\end{array}$ & $\begin{array}{l}-0.046 \\
(-0.61)\end{array}$ & $\begin{array}{l}0.499 \\
(0.93)\end{array}$ \\
\hline $\begin{array}{l}\text { Logged Value of Nonfuel Mineral } \\
\text { Reserves/Capita, } 1970\end{array}$ & $\begin{array}{c}2.390 * * \\
(2.54)\end{array}$ & $\begin{array}{l}-0.258 \\
(-1.60)\end{array}$ & $\begin{array}{l}0.052 \\
(1.20)\end{array}$ & $\begin{array}{l}-0.295 \\
(-1.59)\end{array}$ \\
\hline Log GDP/capita, 1970 & $\begin{array}{l}0.396 \\
(0.19)\end{array}$ & $\begin{array}{c}-1.070 * * \\
(-2.62)\end{array}$ & $\begin{array}{c}0.365 * * * \\
(3.01)\end{array}$ & $\begin{array}{l}-1.104 * \\
(-1.74)\end{array}$ \\
\hline $\begin{array}{l}\text { Average Gross Fixed Capital } \\
\text { Formation, } 1970-89 \text { ( } \% \text { of GDP) }\end{array}$ & $\begin{array}{l}0.148 \\
(0.80)\end{array}$ & $\begin{array}{l}0.173^{* * *} \\
(4.38)\end{array}$ & $\begin{array}{l}0.011 \\
(1.09)\end{array}$ & $\begin{array}{c}0.171 * * * \\
(4.32)\end{array}$ \\
\hline $\begin{array}{l}\text { Average Years of Schooling, 1970- } \\
90\end{array}$ & $\begin{array}{l}-0.694 \\
(-1.57)\end{array}$ & $\begin{array}{l}0.177 \\
(1.29)\end{array}$ & $\begin{array}{c}0.103^{* *} \\
(2.60)\end{array}$ & $\begin{array}{l}0.090 \\
(0.55)\end{array}$ \\
\hline $\begin{array}{l}\text { Average Growth in Population, } \\
1970-89(\%)\end{array}$ & $\begin{array}{l}-0.454 \\
(-0.34)\end{array}$ & $\begin{array}{c}-0.590 * * \\
(-2.06)\end{array}$ & $\begin{array}{l}-0.030 \\
(-0.34)\end{array}$ & $\begin{array}{l}-0.459 \\
(-1.38)\end{array}$ \\
\hline Constant & $\begin{array}{l}-9.079 \\
(-0.61)\end{array}$ & $\begin{array}{c}6.648^{* *} \\
(2.53)\end{array}$ & $\begin{array}{c}-3.007 * * * \\
(-3.78)\end{array}$ & $\begin{array}{l}6.723 \\
(1.52)\end{array}$ \\
\hline Observations & 86 & 86 & 93 & 93 \\
\hline $\begin{array}{l}R^{2} \\
\text { F-test of Instruments }\end{array}$ & $\begin{array}{l}0.602 \\
14.72\end{array}$ & 0.546 & $\begin{array}{c}0.824 \\
2.61\end{array}$ & 0.499 \\
\hline Anderson Canon. Corr. & & 25.47 & & 5.84 \\
\hline Underidentification Test (p-value) & & $(0.00)$ & & $(0.05)$ \\
\hline $\begin{array}{l}\text { Sargan Overidentification Test } \\
\text { (p-value) }\end{array}$ & & $\begin{array}{c}0.74 \\
(0.39)\end{array}$ & & $\begin{array}{c}0.41 \\
(0.52)\end{array}$ \\
\hline Durbin Wu Hausman Endogeneity & & 0.69 & & 0.90 \\
\hline Test (p-value) & & $(0.49)$ & & $(0.37)$ \\
\hline Endogeneity Test (p-value) & & $0.58(0.44)$ & & $0.67(0.41)$ \\
\hline $\begin{array}{l}\text { CLR of Endogenous Variable p- } \\
\text { value }\end{array}$ & & 0.88 & & 0.88 \\
\hline
\end{tabular}


Table A6: Disaggregated Abundance 1996-2008

\begin{tabular}{|c|c|c|c|c|}
\hline & $\begin{array}{c}1) \\
\text { Exports of Point } \\
\text { Resources, } \\
\text { Average 1996- } \\
2008 \text { (\% GDP) } \\
\end{array}$ & $\begin{array}{c}\text { (2) } \\
\text { Average Growth } \\
\text { in GDP/Capita, } \\
\text { 1996-2008, } \\
\text { (Constant 1990\$) } \\
\end{array}$ & $\begin{array}{c}\text { (3) } \\
\text { Rule of Law, } \\
\text { Average of } \\
\text { 1996-2008 }\end{array}$ & $\begin{array}{c}\text { (4) } \\
\text { Average Growth } \\
\text { in GDP/Capita, } \\
\text { 1996-2008, } \\
\text { (Constant 1990\$) }\end{array}$ \\
\hline Rule of Law, Average of 1996-2008 & & & & $\begin{array}{c}1.822^{* * \mathrm{a}} \\
(2.00)\end{array}$ \\
\hline $\begin{array}{l}\text { Exports of Point Resources, average } \\
\text { 1996-2008 (\% GDP) }\end{array}$ & & $\begin{array}{l}-0.061^{\mathrm{a}} \\
(-1.40)\end{array}$ & & \\
\hline $\begin{array}{l}\text { Average Openness, 1950-69 } \\
\text { (Ex+Im/GDP) }\end{array}$ & $\begin{array}{l}11.513^{* * *} \\
\quad(4.67)\end{array}$ & & & \\
\hline Presidential Regime Dummy, 1970s & $\begin{array}{l}1.208 \\
(0.61)\end{array}$ & & & \\
\hline $\begin{array}{l}\text { Absolute Value of Latitude on } 0-1 \\
\text { scale }\end{array}$ & & & $\begin{array}{c}1.131^{* *} \\
(2.55)\end{array}$ & \\
\hline $\begin{array}{l}\text { Fraction of Population Speaking a } \\
\text { European Language }\end{array}$ & $\begin{array}{l}-2.578 \\
(-1.25)\end{array}$ & $\begin{array}{l}0.659 \\
(1.07)\end{array}$ & $\begin{array}{c}0.596 * * * \\
(3.36)\end{array}$ & \\
\hline $\begin{array}{l}\text { Logged Value of Oil } \\
\text { Reserves/Capita, } 1971\end{array}$ & $\begin{array}{l}8.589 * \\
(1.97)\end{array}$ & $\begin{array}{l}-0.016 \\
(-0.03)\end{array}$ & $\begin{array}{c}-0.315^{* * *} \\
(-3.03)\end{array}$ & $\begin{array}{l}0.048 \\
(0.11)\end{array}$ \\
\hline $\begin{array}{l}\text { Logged Value of Natural Gas } \\
\text { Reserves/Capita, } 1971\end{array}$ & $\begin{array}{l}-2.029 \\
(-0.31)\end{array}$ & $\begin{array}{c}1.428 * * \\
(2.20)\end{array}$ & $\begin{array}{l}0.267 \\
(1.39)\end{array}$ & $\begin{array}{l}0.985 \\
(1.39)\end{array}$ \\
\hline $\begin{array}{l}\text { Logged Value of Coal } \\
\text { Reserves/Capita, } 1971\end{array}$ & $\begin{array}{l}2.336 \\
(1.09)\end{array}$ & $\begin{array}{l}0.421 \\
(1.54)\end{array}$ & $\begin{array}{l}-0.007 \\
(-0.11)\end{array}$ & $\begin{array}{c}0.397^{*} \\
(1.69)\end{array}$ \\
\hline $\begin{array}{l}\text { Logged Value of Nonfuel Mineral } \\
\text { Reserves/Capita, } 1970\end{array}$ & $\begin{array}{c}1.556^{* *} \\
(2.17)\end{array}$ & $\begin{array}{l}-0.193 \\
(-1.32)\end{array}$ & $\begin{array}{l}-0.027 \\
(-0.68)\end{array}$ & $\begin{array}{c}-0.256^{*} \\
(-1.81)\end{array}$ \\
\hline Log GDP/capita, 1970 & $\begin{array}{l}-1.967 \\
(-0.95)\end{array}$ & $\begin{array}{c}-1.487 * * * \\
(-3.79)\end{array}$ & $\begin{array}{l}0.343 * * * \\
(3.07)\end{array}$ & $\begin{array}{c}-1.902 * * * \\
(-3.15)\end{array}$ \\
\hline $\begin{array}{l}\text { Average Fixed Capital Formation, } \\
\text { 1996-2008 (Share of GDP) }\end{array}$ & $\begin{array}{l}0.135 \\
(0.72)\end{array}$ & $\begin{array}{l}0.115^{* * *} \\
(3.58)\end{array}$ & $\begin{array}{l}0.029 * * * \\
(3.38)\end{array}$ & $\begin{array}{l}0.046 \\
(1.09)\end{array}$ \\
\hline $\begin{array}{l}\text { Average Years of Schooling, 1995- } \\
2000\end{array}$ & $\begin{array}{l}-0.275 \\
(-0.55)\end{array}$ & $\begin{array}{l}0.393^{* * *} \\
(3.24)\end{array}$ & $\begin{array}{c}0.149 * * * \\
(4.33)\end{array}$ & $\begin{array}{l}0.008 \\
(0.05)\end{array}$ \\
\hline $\begin{array}{l}\text { Average Yearly Growth in } \\
\text { Population, 1996-2008 }\end{array}$ & $\begin{array}{c}-2.149 * * \\
(-2.17)\end{array}$ & $\begin{array}{l}-0.046 \\
(-0.19)\end{array}$ & $\begin{array}{c}0.171^{* *} \\
(2.42)\end{array}$ & $\begin{array}{l}-0.189 \\
(-0.69)\end{array}$ \\
\hline Constant & $\begin{array}{l}11.690 \\
(0.84)\end{array}$ & $\begin{array}{c}8.291 * * * \\
(3.13)\end{array}$ & $\begin{array}{c}-4.157 * * * \\
(-5.54)\end{array}$ & $\begin{array}{c}14.196 * * * \\
(2.81)\end{array}$ \\
\hline Observations & 88 & 88 & 91 & 91 \\
\hline $\begin{array}{l}R^{2} \\
\text { F-test of Instruments }\end{array}$ & $\begin{array}{c}0.599 \\
9.57\end{array}$ & 0.383 & $\begin{array}{c}0.861 \\
7.64\end{array}$ & 0.340 \\
\hline Anderson Canon. Corr. & & 18.49 & & 15.23 \\
\hline Underidentification Test (p-value) & & $(0.00)$ & & $(0.00)$ \\
\hline $\begin{array}{l}\text { Sargan Overidentification Test } \\
\text { (p-value) }\end{array}$ & & $\begin{array}{c}0.18 \\
(0.67)\end{array}$ & & $\begin{array}{c}0.53 \\
(0.47)\end{array}$ \\
\hline Durbin Wu Hausman Endogeneity & & 1.10 & & 1.12 \\
\hline Test (p-value) & & $(0.23)$ & & $(0.27)$ \\
\hline Endogeneity Test (p-value) & & $1.44(0.23)$ & & $1.49(0.22)$ \\
\hline $\begin{array}{l}\text { CLR of Endogenous Variable p- } \\
\text { value }\end{array}$ & & 0.18 & & 0.06 \\
\hline
\end{tabular}




\section{Table A7: Change over Time in the Effect of Resource Abundance}

\begin{tabular}{|c|c|c|c|c|}
\hline & Resource Dependence & $\begin{array}{l}\text { Growth from Resource } \\
\text { Dependence }\end{array}$ & Institutional Quality & $\begin{array}{l}\text { Growth from } \\
\text { Institutional Quality }\end{array}$ \\
\hline Aggregated & Unchanged & Unchanged & Worsened* & Unchanged \\
\hline Oil & Worsened** & Unchanged & Unchanged & Unchanged \\
\hline Natural Gas & Improved* & Improved $* * *$ & Unchanged & Improved** \\
\hline Coal & Worsened** & Unchanged & Unchanged & Unchanged \\
\hline Non-fuel & Unchanged & Unchanged & Worsened** & Unchanged \\
\hline \multicolumn{5}{|c|}{$\begin{array}{l}\text { Wald test of the simple linear hypothesis that the corresponding coefficients in tables A3-6 are the same. } \\
* \mathrm{p}<.10, * * \mathrm{p}<.05, * * * \mathrm{p}<.01 \\
\text { "Improvement" is considered a more positive effect except in the case of resource dependence where improvement is considered a more negative } \\
\text { effect. }\end{array}$} \\
\hline
\end{tabular}

Table A8: 3SLS for 1970-1989

\begin{tabular}{|c|c|c|c|c|}
\hline & $\begin{array}{c}(1) \\
\text { Average Mineral } \\
\text { Resource } \\
\text { Exports/GDP, } \\
\text { 1970-1989 (\%) } \\
\end{array}$ & $\begin{array}{c}\text { (2) } \\
\text { Average Growth } \\
\text { in GDP/Capita, } \\
\text { 1970-1989 } \\
\text { (Constant 1990\$) }\end{array}$ & $\begin{array}{c}(3) \\
\text { Average Mineral } \\
\text { Resource } \\
\text { Exports/GDP, } \\
\text { 1970-1989 (\%) } \\
\end{array}$ & $\begin{array}{c}\text { (4) } \\
\text { Average Growth } \\
\text { in GDP/Capita, } \\
\text { 1970-1989 } \\
\text { (Constant 1990\$) }\end{array}$ \\
\hline $\begin{array}{l}\text { Average Mineral Resource } \\
\text { Exports/GDP, 1970-89 (\%) }\end{array}$ & & $\begin{array}{l}-0.007^{\mathrm{a}} \\
(-0.19)\end{array}$ & & $\begin{array}{l}-0.013^{\mathrm{a}} \\
(-0.42)\end{array}$ \\
\hline $\begin{array}{l}\text { Logged Value of Oil } \\
\text { Reserves/Capita 1971) }\end{array}$ & $\begin{array}{l}1.719 \\
(1.08)\end{array}$ & $\begin{array}{l}0.428 \\
(1.25)\end{array}$ & & \\
\hline $\begin{array}{l}\text { Logged Value of Natural Gas } \\
\text { Reserves/Capita, } 1971\end{array}$ & $\begin{array}{l}6.603 * * \\
(2.36)\end{array}$ & $\begin{array}{c}-1.385^{* *} \\
(-2.01)\end{array}$ & & \\
\hline $\begin{array}{l}\text { Logged Value of Coal } \\
\text { Reserves/Capita, } 1971\end{array}$ & $\begin{array}{l}-2.415 \\
(-1.60)\end{array}$ & $\begin{array}{l}0.113 \\
(0.31)\end{array}$ & & \\
\hline $\begin{array}{l}\text { Logged Value of Nonfuel Mineral } \\
\text { Reserves/Capita, } 1970\end{array}$ & $\begin{array}{c}2.383 * * * \\
(4.24)\end{array}$ & $\begin{array}{l}-0.258^{*} \\
(-1.77)\end{array}$ & & \\
\hline $\begin{array}{l}\text { Norman Log Value of Fuel } \\
\text { Nonfuel Mineral Stocks, } 1970 \\
\text { (US\$/Capita) }\end{array}$ & & & $\begin{array}{c}1.446 * * * \\
(5.40)\end{array}$ & $\begin{array}{l}-0.070 \\
(-1.09)\end{array}$ \\
\hline $\begin{array}{l}\text { Observations } \\
R^{2}\end{array}$ & $\begin{array}{c}86 \\
0.602\end{array}$ & $\begin{array}{c}86 \\
0.551\end{array}$ & $\begin{array}{c}83 \\
0.592\end{array}$ & $\begin{array}{c}83 \\
0.539\end{array}$ \\
\hline
\end{tabular}


Table A9: 3SLS for 1996-2008

\begin{tabular}{|c|c|c|c|c|}
\hline & $\begin{array}{c}(1) \\
\text { Exports of Point } \\
\text { Resources, } \\
\text { Average 1996- } \\
2008 \text { (\% GDP) } \\
\end{array}$ & $\begin{array}{c}(2) \\
\text { Average Growth } \\
\text { in GDP/Capita, } \\
\text { 1996-2008, } \\
\text { (Constant 1990\$) }\end{array}$ & $\begin{array}{c}\text { (3) } \\
\text { Exports of Point } \\
\text { Resources, } \\
\text { Average 1996- } \\
2008 \text { (\% GDP) } \\
\end{array}$ & $\begin{array}{c}(4) \\
\text { Average Growth } \\
\text { in GDP/Capita, } \\
\text { 1996-2008, } \\
\text { (Constant 1990\$) }\end{array}$ \\
\hline $\begin{array}{l}\text { Exports of Point Resources, } \\
\text { average 1996-2008 (\% GDP) }\end{array}$ & & $\begin{array}{l}-0.061^{\mathrm{a}} \\
(-1.48)\end{array}$ & & $\begin{array}{l}-0.033^{\mathrm{a}} \\
(-0.87)\end{array}$ \\
\hline $\begin{array}{l}\text { Logged Value of Oil } \\
\text { Reserves/Capita, } 1971\end{array}$ & $\begin{array}{c}8.581 * * * \\
(5.04)\end{array}$ & $\begin{array}{l}-0.016 \\
(-0.04)\end{array}$ & & \\
\hline $\begin{array}{l}\text { Logged Value of Natural Gas } \\
\text { Reserves/Capita, } 1971\end{array}$ & $\begin{array}{l}-2.016 \\
(-0.64)\end{array}$ & $\begin{array}{c}1.428^{* *} \\
(2.32)\end{array}$ & & \\
\hline $\begin{array}{l}\text { Logged Value of Coal } \\
\text { Reserves/Capita, } 1971\end{array}$ & $\begin{array}{c}2.364^{*} \\
(1.81)\end{array}$ & $\begin{array}{l}0.421 \\
(1.63)\end{array}$ & & \\
\hline $\begin{array}{l}\text { Logged Value of Nonfuel Mineral } \\
\text { Reserves/Capita, } 1970\end{array}$ & $\begin{array}{c}1.563^{* *} \\
(2.36)\end{array}$ & $\begin{array}{l}-0.193 \\
(-1.39)\end{array}$ & & \\
\hline $\begin{array}{l}\text { Norman Log Value of Fuel } \\
\text { Nonfuel Mineral Stocks, } 1970 \\
\text { (US\$/capita) }\end{array}$ & & & $\begin{array}{l}1.682^{* * *} \\
(5.42)\end{array}$ & $\begin{array}{l}0.057 \\
(0.77)\end{array}$ \\
\hline $\begin{array}{l}\text { Observations } \\
R^{2}\end{array}$ & $\begin{array}{c}88 \\
0.599\end{array}$ & $\begin{array}{c}88 \\
0.335\end{array}$ & $\begin{array}{c}85 \\
0.507\end{array}$ & $\begin{array}{c}85 \\
0.317\end{array}$ \\
\hline$t$ statistics in parentheses & $* \mathrm{p}<.10, * * \mathrm{p}$ & $5, * * * \mathrm{p}<.01$ & ${ }^{a}$ fitted value & n previous column \\
\hline
\end{tabular}


Table A10: Disaggregated Abundance 1970-1989 with Grubbs

\begin{tabular}{|c|c|c|c|c|}
\hline & $\begin{array}{c}(1) \\
\text { Average } \\
\text { Mineral } \\
\text { Resource } \\
\text { Exports/GDP, } \\
\text { 1970-1989 (\%) }\end{array}$ & $\begin{array}{c}(2) \\
\text { Average Growth } \\
\text { in GDP/Capita, } \\
\text { 1970-1989 } \\
\text { (Constant 1990\$) }\end{array}$ & $\begin{array}{c}\text { (3) } \\
\text { Rule of Law, } \\
1996\end{array}$ & $\begin{array}{c}(4) \\
\text { Average Growth } \\
\text { in GDP/Capita, } \\
\text { 1970-1989 } \\
\text { (Constant 1990\$) }\end{array}$ \\
\hline Rule of Law, 1996 & & & & $\begin{array}{l}0.628^{\mathrm{a}} \\
(0.66)\end{array}$ \\
\hline $\begin{array}{l}\text { Average Mineral Resource } \\
\text { Exports/GDP, 1970-89 (\%) }\end{array}$ & & $\begin{array}{l}-0.106^{\mathrm{a}} \\
(-0.75)\end{array}$ & & \\
\hline $\begin{array}{l}\text { Logged Value of Oil Reserves/Capita, } \\
1971\end{array}$ & $\begin{array}{l}1.712 \\
(1.14)\end{array}$ & $\begin{array}{l}1.148 \\
(1.11)\end{array}$ & $\begin{array}{l}-0.351 \\
(-1.04)\end{array}$ & $\begin{array}{l}1.282 \\
(1.21)\end{array}$ \\
\hline $\begin{array}{l}\text { Logged Value of Natural Gas } \\
\text { Reserves/Capita, } 1971\end{array}$ & $\begin{array}{l}9.089 \\
(1.26)\end{array}$ & $\begin{array}{l}2.763 \\
(0.50)\end{array}$ & $\begin{array}{l}-1.817 \\
(-1.11)\end{array}$ & $\begin{array}{l}2.627 \\
(0.52)\end{array}$ \\
\hline $\begin{array}{l}\text { Logged Value of Nonfuel Mineral } \\
\text { Reserves/Capita, } 1970\end{array}$ & $\begin{array}{c}1.285^{* *} \\
(2.36)\end{array}$ & $\begin{array}{l}0.237 \\
(0.95)\end{array}$ & $\begin{array}{l}-0.076 \\
(-1.04)\end{array}$ & $\begin{array}{l}-0.066 \\
(-0.32)\end{array}$ \\
\hline Observations & 65 & 59 & 69 & 68 \\
\hline $\begin{array}{l}R^{2} \\
\text { E-test }\end{array}$ & 0.332 & 0.689 & 0.852 & 0.655 \\
\hline $\begin{array}{l}\text { Anderson Canon. Corr. } \\
\text { Underidentification Test (p-value) }\end{array}$ & & $\begin{array}{l}10.69 \\
(0.00)\end{array}$ & & 10.31 \\
\hline $\begin{array}{l}\text { Sargan Overidentification Test } \\
\text { (p-value) }\end{array}$ & & $\begin{array}{l}1.63 \\
(0.20)\end{array}$ & & $\begin{array}{c}0.12 \\
(0.73)\end{array}$ \\
\hline $\begin{array}{l}\text { Durbin Wu Hausman Endogeneity Test } \\
\text { (p-value) }\end{array}$ & & $\begin{array}{c}0.09 \\
(0.93)\end{array}$ & & $\begin{array}{c}0.35 \\
(0.73)\end{array}$ \\
\hline Endogeneity Test (p-value) & & $0.01(0.92)$ & & $0.16(0.69)$ \\
\hline CLR of Endogenous Variable p-value & & 0.76 & & 0.55 \\
\hline
\end{tabular}


Table A11: Disaggregated Abundance 1996-2008 with Grubbs

\begin{tabular}{|c|c|c|c|c|}
\hline & $\begin{array}{c}(1) \\
\text { Exports of } \\
\text { Point } \\
\text { Resources, } \\
\text { average 1996- } \\
2008 \text { (\% GDP) } \\
\end{array}$ & $\begin{array}{c}(2) \\
\text { Average Growth } \\
\text { in GDP/Capita, } \\
\text { 1996-2008, } \\
\text { (Constant 1990\$) }\end{array}$ & $\begin{array}{c}\text { (3) } \\
\text { Rule of Law, } \\
\text { Average of } \\
\text { 1996-2008 }\end{array}$ & $\begin{array}{c}\text { (4) } \\
\text { Average Growth } \\
\text { in GDP/Capita, } \\
\text { 1996-2008, } \\
\text { (Constant 1990\$) }\end{array}$ \\
\hline Rule of Law, Average of 1996-008 & & & & $\begin{array}{l}0.750^{\mathrm{a}} \\
(0.98)\end{array}$ \\
\hline $\begin{array}{l}\text { Exports of Point Resources, Average } \\
\text { 1996-2008 (\% GDP) }\end{array}$ & & $\begin{array}{l}-0.096^{\mathrm{a}} \\
(-0.90)\end{array}$ & & \\
\hline $\begin{array}{l}\text { Logged Value of Oil Reserves/Capita, } \\
1971\end{array}$ & $\begin{array}{l}2.456 \\
(1.06)\end{array}$ & $\begin{array}{l}-0.534 \\
(-0.56)\end{array}$ & $\begin{array}{l}0.085 \\
(0.30)\end{array}$ & $\begin{array}{l}-1.420 \\
(-1.47)\end{array}$ \\
\hline $\begin{array}{l}\text { Logged Value of Natural Gas } \\
\text { Reserves/Capita, } 1971\end{array}$ & $\begin{array}{l}7.087 \\
(0.54)\end{array}$ & $\begin{array}{l}8.141 \\
(1.64)\end{array}$ & $\begin{array}{c}-3.103 * * \\
(-2.26)\end{array}$ & $\begin{array}{l}14.137 * * * \\
(2.81)\end{array}$ \\
\hline $\begin{array}{l}\text { Logged Value of Nonfuel Mineral } \\
\text { Reserves/Capita, } 1970\end{array}$ & $\begin{array}{c}1.859 * * \\
(2.13)\end{array}$ & $\begin{array}{l}0.344 \\
(1.35)\end{array}$ & $\begin{array}{c}-0.140 * * \\
(-2.30)\end{array}$ & $\begin{array}{l}0.206 \\
(0.98)\end{array}$ \\
\hline $\begin{array}{l}\text { Observations } \\
R^{2} \\
\text { F-test of Instruments }\end{array}$ & $\begin{array}{c}59 \\
0.489 \\
2.59\end{array}$ & $\begin{array}{c}58 \\
0.475\end{array}$ & $\begin{array}{c}64 \\
0.902 \\
10.14\end{array}$ & $\begin{array}{c}63 \\
0.446\end{array}$ \\
\hline Anderson Canon. Corr. & & 10.68 & & 18.70 \\
\hline Underidentification Test (p-value) & & $(0.00)$ & & $(0.00)$ \\
\hline $\begin{array}{l}\text { Sargan Overidentification Test } \\
\text { (p-value) }\end{array}$ & & $\begin{array}{c}0.19 \\
(0.66)\end{array}$ & & $\begin{array}{c}0.12 \\
(0.73)\end{array}$ \\
\hline $\begin{array}{l}\text { Durbin Wu Hausman Endogeneity Test } \\
\text { (p-value) }\end{array}$ & & $\begin{array}{c}0.72 \\
(0.48)\end{array}$ & & $\begin{array}{c}0.26 \\
(0.80)\end{array}$ \\
\hline Endogeneity Test (p-value) & & $0.79(0.37)$ & & $0.01(0.93)$ \\
\hline CLR of Endogenous Variable p-value & & 0.37 & & 0.34 \\
\hline
\end{tabular}




\section{REFERENCES}

Auty, R.M. 1993. Sustaining Development in Mineral Economies: The Resource Curse Thesis. London and New York: Routledge.

Baum, C.F., M.E. Schaffer, and S. Stillman. 2007. "Enhanced routines for instrumental variables/GMM estimation and testing.” Stata Journal 7(4): 465-506.

Barro, J.R. 1999. “Determinants of Democracy.” Journal of Political Economy 107(6): S158-83.

Barro, R.J., and J.-W. Lee. 2000. "International Data on Educational Attainment: Updates and Implications.” Working Paper No. 42. Cambridge, MA: Center for International Development, Harvard University.

Beck, T., G. Clarke, A Groff, P. Keefer, and P. Walsh. 2005. "New Tools in Comparative Political Economy: The Database of Political Institutions.” World Bank Economic Review 15: $165-176$.

Boschini, A.D., J. Pettersson, and J. Roine. 2007. "Resource Curse or Not: A Question of Appropriability.” Scandinavian Journal of Economics 109: 593-617.

Brunnschweiler, C.N., and E.H. Bulte. 2008. “The Resource Curse Revisited and Revised: a Tale of Paradoxes and Red Herrings.” Journal of Environmental Economics and Management 55: 248-264.

Chaudhry, K.A. 1989. "The Price of Wealth: Business and State in Labor Remittance and Oil Economies.” International Organization 43: 101-145.

Corden, M.W., and J.P. Neary. 1982. "Booming Sector and De-Industrialisation in a Small Open Economy.” The Economic Journal 90(December): 825-848.

Davis, J., R. Ossowski, J. Daniel, and S. Barnett. 2001. "Oil funds: problems posing as solutions?” Finance and Development 38(4): 56-9.

Ding, N., and B.C. Field. 2005. "Natural Resource Abundance and Economic Growth.” Land Economics 81: 496-502.

Easterly, W. 2005. “Inequality Does Cause Underdevelopment.” Working Paper No. 1. Washington, DC: Center for Global Development.

Frankel, J.A. 2010. “The Natural Resource Curse: A Survey.” Working Paper 15836. Cambridge, MA: National Bureau of Economic Research (NBER).

Hall, R.E., and C.I. Jones. 1999. "Why do Some Countries Produce So Much More Output Per Worker Than Others?” The Quarterly Journal of Economics 114: 83-116. 
Heston, A., R. Summer, and B. Aten. 2009. Penn World Table Version 6.1. Philadelphia, PA: Center for International Comparisons of Production, Income and Prices at the University of Pennsylvania.

Humphreys, M., J.D. Sachs, and J.E. Stiglitz. 2007. Escaping the Resource Curse. New York: Columbia University Press.

Isham, J., M. Woolcock, L. Pritchett, and G. Busby. 2005. “The Varieties of Resource Experience: Natural Resource Export Structures and the Political Economy of Economic Growth.” World Bank Economic Review 19(2): 141-74.

Kaufmann, D., A. Kraay, and M. Mastruzzi. 2009. "Governance Matters VIII: Aggregate and Individual Governance Indicators 1996-2008.” The World Bank Development Research Group Macroeconomics and Growth Team: 1-103.

Knack, S., and P. Keefer. 2003. "Institutions and Economic Performance: Cross Country Tests Using Alternative Institutional Measures.” in S. Knack (ed.), Democracy, Governance, and Growth. Ann Arbor, MI: University of Michigan Press.

La Porta, R., F. Lopez-de-Silanes, A. Shleifer, and R. Vishny. 1999. "The Quality of Government.” Journal of Law, Economics and Organization 15(1); $222-79$.

Larsen, E.R. 2006. "Escaping the Resource Curse and the Dutch Disease? When and Why Norway Caught Up with and Forged Ahead of its Neighbors." American Journal of Economics and Sociology 65: 605-40.

Leite, C., and J. Weidmann. 1999. "Does mother nature corrupt? Natural resources, corruption, and economic growth.” Working Paper 99/85. Washington, DC: International Monetary Fund (IMF).

Luong, P.J., and E. Weinthal. 2010. Oil is Not a Curse: Ownership Structure and Institutions in Soviet Successor States. Cambridge, UK: Cambridge University Press.

Mehlum, H., K. Moene, and R. Torvik. 2006. “Cursed by Resources or Institutions?” The World Economy 29(8): 1117-31.

Moreira, M.J. 2003. “A Conditional Likelihood Ratio Test for Structural Models.” Econometrica 71(4): 1027-48.

Murshed, S.M. 2004. "When does natural resource abundance lead to a resource curse?" Discussion Paper 04-01. London: International Institute for Environment and Development.

Norman, C.S. 2009. "Rule of Law and the Resource Curse: Abundance versus Intensity." Environmental and Resource Economics 43: 183-207. 
Persson, T., and G. Tabellini. 2004. "Constitutional Rules and Fiscal Policy Outcomes.” American Economic Review 94: 25-46.

Ploeg, F. van der, and S. Poelhekke. 2010. “The Pungent Smell of 'Red Herrings': Subsoil Assets, Rents, Volatility, and the Resource Curse.” Journal of Environmental Economics and Management 60: 44-55.

Ross, M. 2001. “Does Oil Hinder Democracy?” World Politics 53(3): 325-61.

Quinn, J.J., and R.T. Conway. 2007. “The Resource Curse Redux: What Role Ownership?” Paper presented at the annual meeting of the International Studies Association 48th Annual Convention, Chicago, IL, February 28. Available at: http://www.allacademic.com/meta/p179991_index.html

Sachs, J.D., and A.M. Warner. 1995. "Natural Resource Abundance and Economic Growth." Working Paper W5398. Cambridge, MA: National Bureau of Economic Research (NBER).

. 2001. "The Curse of Natural Resources.” European Economic Review 45: 827-38.

Sala-i-Martin, X., and A. Subramanian. 2003. "Addressing the Natural Resource Curse: an Illustration from Nigeria.” Working Paper No. 9804: Cambridge, MA: National Bureau of Economic Research (NBER).

Shafer, M.D. 1994. Winners and Losers: How Sectors Shape the Developmental Prospects of States. Ithaca, NY: Cornell University Press.

Shambayati, H. 1994. "The Rentier State, Interest Groups, and the Paradox of Autonomy: State and Business in Iran and Turkey.” Comparative Politics 26(April): 307-31.

Shaw, P., M.-S. Katsaiti, and M. Jurgilas. 2010. "Corruption and Growth under Weak Identification.” Economic Inquiry. Available at: http://onlinelibrary.wiley.com/doi/10.1111/j.1465-7295.2009.00276.x/pdf

Shleifer, A., and R.W. Vishny. 1993. “Corruption.” The Quarterly Journal of Economics 108(3): 599-617.

Stock, J.H., J.H. Wright, and M. Yogo. 2002. "A Survey of Weak Instruments and Weak Identification in Generalized Method of Moments." Journal of Business and Economic Statistics 20(4): 518-29.

U.S. Energy Information Administration. 2010. “Petroleum Navigator: Spot Prices.” Available at: http://www.eia.doe.gov/dnav/pet/PET_PRI_SPT_S1_A.htm.

U.S. Energy Information Administration. 2010. “Coal Imports and Exports.” Available at: http://www.eia.doe.gov/energyexplained/index.cfm?page=coal_imports 
UNCTAD. 2009. "Handbook of Statistics.” Available at: http://www.unctad.org/Templates/Page.asp?intItemID=1890\&lang=1

Weinthal, E., and P. Jones Luong, 2006. "Combating the Resource Curse: An Alternative Solution to Managing Mineral Wealth.” Perspectives on Politics 4(1): 35-53. 